\section{Should rituximab be used to treat antineutrophil cytoplasmic antibody associated vasculitis?}

\section{O Flossmann, R B Jones, D R W Jayne, R A Luqmani}

\section{It remains to be seen whether rituximab can live up to the high expectations and offer a more effective treatment for patients with AASV}

T he antineutrophil cytoplasmic antibody (ANCA) associated systemic vasculitides (AASV) are a group of multisystem diseases characterised by a predominantly small vessel vasculitis and the occurrence of ANCA in most, but not all, cases. The two main forms of AASV are distinguished by the presence of granulomata and destructive lesions of the upper respiratory tract in Wegener's granulomatosis (WG), which are absent in microscopic polyangiitis (MPA).

Despite significant progress in the management of these diseases, there are still no fully satisfactory treatments for patients with either refractory or frequently relapsing disease. Current standard immunosuppressive treatment reduces mortality substantially, but a large proportion of patients, particularly those with WG, follow a frequently relapsing course. ${ }^{1}$ These patients are at high risk of cumulative toxicity from current treatments and also of increasing damage due to active disease. Cytotoxic drugs, especially cyclophosphamide, carry a substantial risk of severe side effects such as infertility and in the long term, malignancy (particularly bladder carcinoma), which makes them unappealing for the treatment of younger patients; additionally, there are problems of leucopenia and sepsis, which are of great concern, especially for the elderly. ${ }^{3}$ The advent of an effective and safe treatment for AASV would be a major advance in the management of these diseases.

Rituximab, a chimeric, monoclonal IgGl antibody directed against CD20, leads to destruction of $B$ cells via complement mediated lysis and antibody dependent cellular cytotoxicity. It was originally developed as an agent for the treatment of non-Hodgkin's lymphoma. ${ }^{5}$ CD20, which is a transmembrane surface antigen of B cells of unknown biological role, is not expressed on pre-B cells and plasma cells so these cells are not affected by anti-CD20 treatment. Rituximab leads to a swift depletion of circulating B cells, which become undetectable in the peripheral blood. Peripheral B cell depletion typically lasts for at least 6 months with subsequent gradual reconstitution of $\mathrm{B}$ cell numbers. Animal experiments suggest that B cells which reside in lymphoid tissue are probably less susceptible than circulating $\mathrm{B}$ cells to the effects of rituximab. ${ }^{6}$

Interest in the use of anti-B cell therapy for autoimmune conditions followed a case report of a coincidental marked improvement in inflammatory arthritis in a patient undergoing treatment with rituximab for lymphoma. ${ }^{7}$ A large randomised controlled trial has demonstrated efficacy in patients with rheumatoid arthritis (RA) whose disease failed to respond to methotrexate. ${ }^{8}$ There have been case series and small trials showing its effectiveness in autoimmune conditions, including systemic lupus erythematosus (SLE) ${ }^{9}$ and other conditions associated with pathological autoantibodies, such as haemolytic anaemia. ${ }^{10}$

\section{"Rituximab is effective in treating autoimmune conditions"}

AASV is characterised by the presence of autoantibodies directed against either myeloperoxidase or proteinase 3 of neutrophils (enzymes found in the primary granules of neutrophils). The importance of these autoantibodies in the pathogenesis and maintenance of vasculitis in AASV is supported by clinical studies and in experimental models. ${ }^{11-14}$ The use of rituximab to deplete B cells would theoretically interfere with the reconstitution of plasma cells and lead to the disruption of ANCA production. Experience in other autoimmune diseases has taught us, however, that B cells play a pivotal role not only in antibody production but also in other aspects of the immune regulation such as immune response regulation, antigen presentation, and cytokine production. In RA and SLE, B cell function is important for the disease process, by mechanisms that are independent of the generation of autoantibodies. ${ }^{15}{ }^{16} \mathrm{~B}$ cells have been implicated in granuloma formation in WG. ${ }^{17}$ Activated B cells are present in higher numbers in patients with active vasculitis than in patients in remission, or healthy controls. ${ }^{18} \mathrm{~B}$ cells are very effective antigen presenting cells. They can activate $\mathrm{T}$ cells, leading to the production of cytokines. B cells also produce a variety of cytokines, including tumour necrosis factor $\alpha(\mathrm{TNF} \alpha)$ and interleukin (IL) 6 , which can be both pro- and antiinflammatory. ${ }^{19}$ The activation of $\mathrm{B}$ cells is regulated by a cytokine called $\mathrm{B}$ lymphocyte stimulator (BlyS) or B cell activating factor (BAFF). Levels of BlyS/ BAFF are raised in patients with SLE and correlate with disease activity. ${ }^{20}$ Similar findings have been reported in AASV. ${ }^{21}$

The evidence of the use of rituximab in AASV is limited to a small number of case reports and uncontrolled clinical studies (table 1). All except one of the published reports showed rituximab to be an effective and safe treatment in AASV, with responses in excess of $90 \%$ of cases. ${ }^{21 a}{ }^{22-26}$ One case series reported a response in only three out of eight patients who had predominantly granulomatous disease manifestations. ${ }^{27}$ These patients had previously failed to respond to standard treatment with cyclophosphamide and steroids and a range of alternative treatments and therefore represent the treatment resistant (refractory) end of the disease spectrum.

There are a number of considerations about the use of rituximab as treatment of AASV in clinical practice. All published studies included patients who had active vasculitis and were intolerant of, or refractory to, standard treatment. In these patients $44 / 53$ (83\%) reached complete remission and a further three achieved partial remission. Fourteen of these patients subsequently relapsed, between 9 and 21 months after treatment. Rituximab was used for re-treatment in some of these patients, with excellent results in most cases. ${ }^{21 a} 22$ Relapses occurred after the reappearance of peripheral $\mathrm{B}$ cells and often in association with a rising ANCA titre. Most patients remained in remission with no treatment or when receiving small doses of corticosteroids despite the reconstitution of peripheral B cells.

The use of rituximab as a remission maintenance agent is less clear. In some case series patients without clinical 


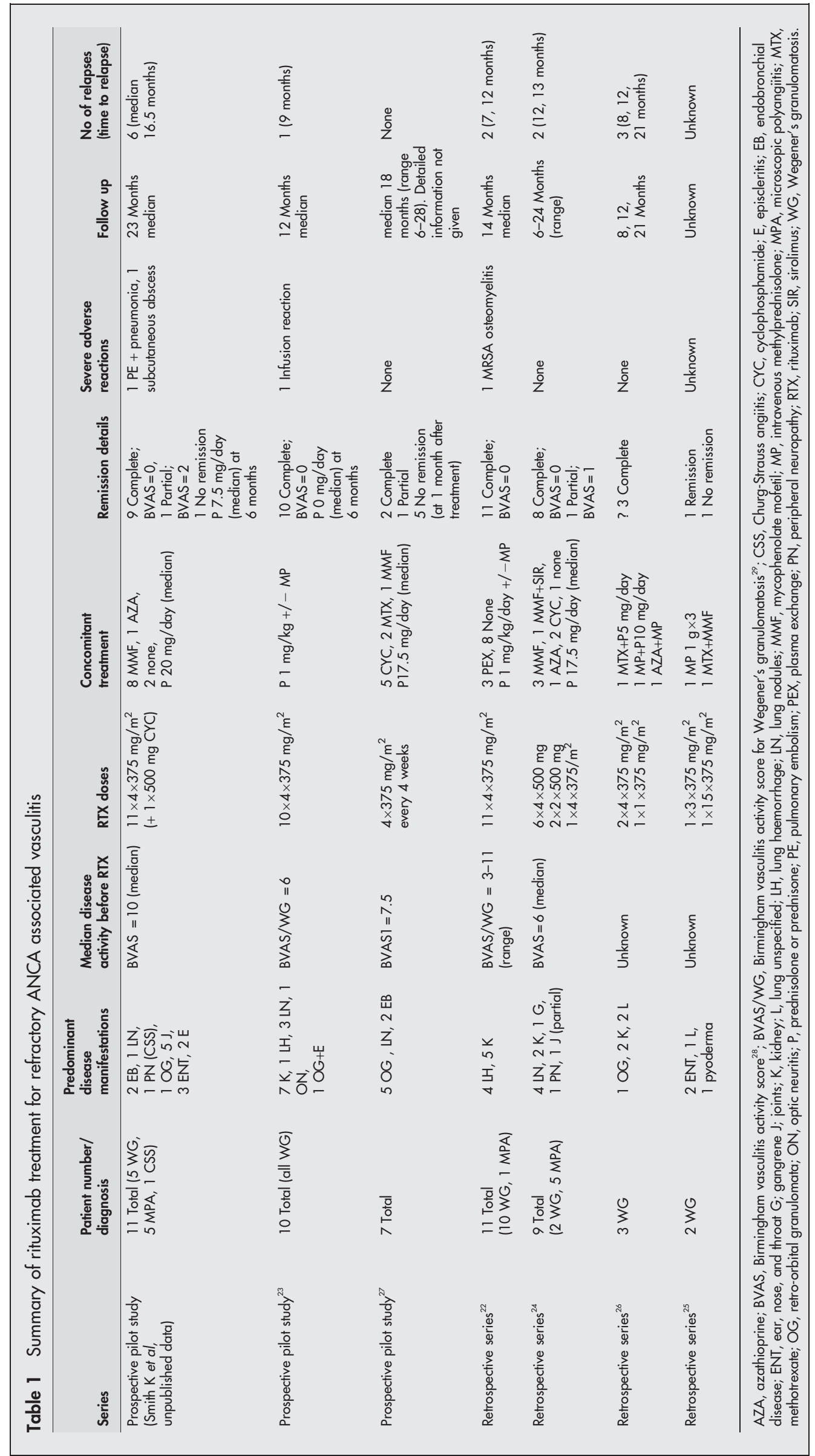


manifestations were retreated because of a rising ANCA titre. These patients remained in remission during the follow up of 12 months. ${ }^{22}$ Whether the initial treatment of patients with newly diagnosed rituximab will lead to long term remission is unknown. Two studies have reported that some clinical features such as retro-orbital granulomata were less responsive than other disease manifestations. ${ }^{26}{ }^{27}$ By contrast, other granulomatous features such as pulmonary nodules and endobronchial disease responded well to treatment. ${ }^{21 a}{ }^{23}$ More work is needed to determine whether or not there is a differential response to rituximab, dependent on the disease manifestation.

\section{"Response to rituximab may vary depending on the disease manifes- tation"}

B cells rapidly become undetectable in the peripheral blood after a successful rituximab infusion. In some patients they remain at very low levels for more than 20 months but in the majority there is a gradual reconstitution of $\mathrm{B}$ cell numbers after 6 months. Although rituximab leads to a reduction of autoantibody titres in a number of clinical conditions (such as SLE), the reduction in ANCA titres is not uniform and not predictive of achieving remission. Some patients achieve stable clinical remission despite maintaining a high ANCA level. Monitoring of ANCA titres and B cell levels is important in order to establish that the treatment has successfully depleted the B cell population, but their role in guiding the need for re-treatment is as yet not established.

In some studies of AASV, rituximab is used in addition to more conventional immunosuppression with cyclophosphamide, methotrexate, azathioprine or mycophenolate mofetil. ${ }^{21 a}{ }^{24-27}$ Others studies, however, did not use any concomitant immunosuppressive treatment except for corticosteroids. ${ }^{22}{ }^{23}$ A potential problem in AASV is that the full therapeutic effect of rituximab may be delayed by up to 3 months, which raises concerns over its suitability as a single agent for patients who are rapidly deteriorating owing to life- or organ threatening disease manifestations.

There is a theoretical risk that patients will develop human anti-chimeric antibodies (HACA), which would either lead to infusion reactions or would abolish the therapeutic effectiveness on repeat dosing. The magnitude of this problem and its clinical importance is so far not known. Reassuringly, in a study of patients with RA, only $4.3 \%$ developed HACAs and no clinically apparent adverse effects were noted. ${ }^{8}$ A variety of dosing regimens have been used, the commonest being four infusions of $375 \mathrm{mg} / \mathrm{m}^{2}$ rituximab given at weekly intervals. ${ }^{5}$ A retrospective analysis of our own practice suggests that different dosing regimens have potentially clinically important different outcomes. Patients who received the regimen as used in the RA trial $(2 \times 1 \mathrm{~g}$ with an interval of 2 weeks $)^{8}$ showed a higher relapse rate than patients treated according to the lymphoma protocol. ${ }^{5}$ Possible explanatory factors include the rapidity and duration of $\mathrm{B}$ cell depletion and the formation of HACAs.

Infusions of rituximab are usually well tolerated in patients with AASV with only minor infusion reactions. The peripheral B cell depletion with rituximab leads to a fall in the serum IgM levels but, crucially, IgG levels are only marginally reduced. This may explain the low rate of severe infections seen in patients. It is not known what effect repeated courses of rituximab will have on the humoral immune system in patients with AASV. The decline in IgM levels suggests that rituximab is likely to interfere with ability to fight new pathogens.

Two large randomised controlled trials of rituximab are currently underway in AASV. It remains to be seen whether rituximab can live up to the high expectations the preliminary results have raised, and offer a safer and more effective treatment for patients with AASV.

Ann Rheum Dis 2006;65:841-844.

doi: $10.1136 /$ ard.2005.048900

\section{Authors' affiliations}

O Flossmann, R A Luqmani, Botnar Research Centre, University of Oxford, Windmill Road, Oxford OX3 7LD, UK

R B Jones, D R W Jayne, Vasculitis Unit, Addenbrooke's Hospital, Hills Road,

Cambridge CB2 $2 Q Q$, UK

Correspondence to: $\operatorname{Dr} R$ A Luqmani, raashid. luqmani@noc.anglox.nhs.uk

\section{REFERENCES}

1 Jayne D, Rasmussen N, Andrassy K, Bacon P, Tervaert JW, Dadoniene J, et al. A randomized trial of maintenance therapy for vasculitis associated with antineutrophil cytoplasmic autoantibodies. N Engl J Med 2003;349:36-44.

2 Exley AR, Bacon PA, Luqmani RA, Kitas GD, Carruthers DM, Moots R. Examination of disease severity in systemic vasculitis from the novel perspective of damage using the vasculitis damage index (VDI). Br J Rheumatol 1998;37:57-63.

3 Hoffman GS, Kerr GS, Leavitt RY, Hallahan CW, Lebovics RS, Travis WD, et al. Wegener granulomatosis: an analysis of 158 patients. Ann Intern Med 1992; 116:488-98.

4 Reinhold-Keller E, Beuge N, Latza U, de Groot K, Rudert $\mathrm{H}$, Nolle B, et al. An interdisciplinary approach to the care of patients with Wegener's granulomatosis: long-term outcome in 155 patients. Arthritis Rheum 2000;43:1021-32.
5 Maloney DG, Grillo-Lopez AJ, White CA, Bodkin D, Schilder RJ, Neidhart JA, et al. IDECC2B8 (rituximab) anti-CD20 monoclonal antibody therapy in patients with relapsed low-grade nonHodgkin's lymphoma. Blood 1997;90:2188-95.

6 Reff ME, Carner K, Chambers KS, Chinn PC, Leonard JE, Raab R, et al. Depletion of B cells in vivo by a chimeric mouse human monoclonal antibody to CD20. Blood 1994;83:435-45.

7 Protheroe A, Edwards JC, Simmons A, Maclennan K, Selby P. Remission of inflammatory arthropathy in association with anti-CD20 therapy for non-Hodgkin's lymphoma. Rheumatology (Oxford) 1999;38:1 150-2.

8 Edwards JC, Szczepanski L, Szechinski J, Filipowicz-Sosnowska A, Emery P, Close DR, et al. Efficacy of B-cell-targeted therapy with rituximab in patients with rheumatoid arthritis. N Engl J Med 2004;350:2572-81.

9 Looney RJ, Anolik JH, Campbell D, Felgar RE, Young $\mathrm{F}$, Arend $\mathrm{U}$, et al. B cell depletion as a novel treatment for systemic lupus erythematosus: a phase I/II dose-escalation trial of rituximab. Arthritis Rheum 2004;50:2580-9.

10 Arzoo K, Sadeghi S, Liebman HA. Treatment of refractory antibody mediated autoimmune disorders with an anti-CD20 monoclonal antibody (rituximab). Ann Rheum Dis 2002;61:922-4.

11 Heeringa P, Tervaert JW. Pathophysiology of ANCA-associated vasculitides: are ANCA really pathogenic? Kidney Int 2004;65:1564-7.

12 Huugen D, Tervaert JW, Heeringa P. Antineutrophil cytoplasmic autoantibodies and pathophysiology: new insights from animal models. Curr Opin Rheumatol 2004;16:4-8.

13 Xiao H, Heeringa P, Hu P, Liu Z, Zhao M, Aratani $Y$, et al. Antineutrophil cytoplasmic autoantibodies specific for myeloperoxidase cause glomerulonephritis and vasculitis in mice. J Clin Invest 2002;1 10:955-63.

14 Weidner S, Neupert W, Goppelt-Struebe M, Rupprecht HD. Antineutrophil cytoplasmic antibodies induce human monocytes to produce oxygen radicals in vitro. Arthritis Rheum 2001;44:1698-706.

15 Chan OT, Hannum LG, Haberman AM, Madaio MP, Shlomchik MJ. A novel mouse with B cells but lacking serum antibody reveals an antibody-independent role for B cells in murine lupus. J Exp Med 1999; 189:1639-48.

16 Takemura S, Klimiuk PA, Braun A, Goronzy JJ, Weyand CM. T cell activation in rheumatoid synovium is B cell dependent. $J$ Immunol 2001; 167:4710-18.

17 Voswinkel J, Mueller A, Kraemer JA, Lamprecht P, Herlyn K, Holl-Ulrich K, et al. B lymphocyte maturation in Wegener's granulomatosis: a comparative analysis of $\mathrm{VH}$ genes from endonasal lesions. Ann Rheum Dis 2006;65:859-64.

18 Popa ER, Stegeman CA, Bos NA, Kallenberg CG Tervaert JW. Differential B- and T-cell activation in Wegener's granulomatosis. J Allergy Clin Immunol 1999;103(5 Pt 1):885-94

19 Mitchison NA. T-cell-B-cell cooperation. Nat Rev Immunol 2004:4:308-12.

20 Collins CE, Gavin AL, Migone TS, Hilbert DM, Nemazee D, Stohl W. B lymphocyte stimulator (BLyS) isoforms in systemic lupus erythematosus: disease activity correlates better with blood leukocyte BLyS mRNA levels than with plasma BLyS protein levels. Arthritis Res Ther 2005;8:R6.

21 Krumbholz M, Specks U, Wick M, Kalled SL, Jenne D, Meinl E. BAFF is elevated in serum of patients with Wegener's granulomatosis. $J$ Autoimmun 2005;25:298-302.

21 a Smith K, Jones R, Burns S, Jayne D. Long term comparison of rituximab treatment for refractory SLE and vasculitis; remission, relapse and retreatment. Arthritis Rheum (in press).

22 Keogh KA, Wylam ME, Stone JH, Specks U. Induction of remission by B lymphocyte depletion in eleven patients with refractory antineutrophil cytoplasmic antibody-associated vasculitis. Arthritis Rheum 2005:52:262-8.

23 Keogh KA, Ytterberg SR, Fervenza FC, Carlson KA, Schroeder DR, Specks U.' Rituximab for refractory Wegener's granulomatosis: report of a prospective, open-label pilot trial. Am J Respir Crit Care Med 2006;173:180-7. 
24 Eriksson P. Nine patients with anti-neutrophil cytoplasmic antibody-positive vasculitis successfully treated with rituximab. J Intern Med 2005;257:540-8.

25 Gottenberg JE, Guillevin L, Lambotte O, Combe B, Allanore $Y$, Cantagrel A, et al. Tolerance and short term efficacy of rituximab in 43 patients with systemic autoimmune diseases. Ann Rheum Dis 2005;64:913-20.
26 Omdal R, Wildhagen K, Hansen T, Gunnarsson R Kristoffersen G. Anti-CD20 therapy of treatmentresistant Wegener's granulomatosis: favourable but temporary response. Scand I Rheumatol 2005;34:229-32.

27 Aries PM, Hellmich B, Voswinkel J, Both $M$, Nölle B, Holl-Ulrich $\mathrm{K}$, et al. Lack of efficacy of rituximab in Wegener's granulomatosis with refractory granulomatous manifestations. Ann Rheum Dis 2006;65:853-8.
28 Luqmani RA, Bacon PA, Moots RJ, Janssen BA, Pall $A$, Emery $P$, et al. Birmingham vasculitis activity score (BVAS) in systemic necrotizing vasculitis. QJM 1994;87:671-8.

29 Stone JH, Hoffman GS, Merkel PA, Min Y-I, Uhlfelder ML, Hellmann DB, et al. A diseasespecific activity index for Wegener's granulomatosis: modification of the Birmingham Vasculitis Activity Score. Arthritis Rheum 2001;44:912-20.

EDITOR: ANNALS OF THE RHEUMATIC DISEASES - THE EULAR JOURNAL

Applications are invited for the post of Editor of the Annals of the Rheumatic Diseases.

$A R D$ is the most cited European rheumatology journal and is the official journal of EULAR. We now seek an editor who can continue to advance its scientific and international reputation while maintaining its relevance to practising rheumatologists world wide.

Applications from specialists in any branch of rheumatology from any country are invited. Joint applications from two or more people willing to act as a team will be considered.

Full editorial support and training will be provided. The journal will fund any necessary locum requirements (the editor is likely to spend 1 to 2 days a week dedicated to journal activities). The successful applicant(s) will be free to select his/her own team of associate editors and board members. The editor of ARD is a non-voting member of the EULAR Executive Committee.

Closing date for applications is 30 June 2006. Interviews will be held on 18 September 2006 at the EULAR offices near Zurich, Switzerland. It is envisaged that the successful candidate will officially take up the post of editor in July 2007. Term of office is 5 years in the first instance with an option to renew for 2 years.

Further details of the post can be discussed with the publishing director, Mrs Alex Williamson and/or the retiring editor Professor Leo van de Putte (Tel: +31 6532 49380, email: L.vandeputte@reuma.umcn.nl). A job description is available on request from Mrs Williamson.

Applications should be sent to Mrs Alex Williamson, BMJ Publishing Group, BMA House, Tavistock Square, London WC1H 9JR, UK. Tel: +44 (0)20 7383 6069/6169; Fax: +44 (0)20 7383 6668; email awilliamson@bmigroup.com 